\title{
Nation State as Security Provider in Human Security
} Issue

\section{Made Fitri Maya Padmi}

Master Programme in International Security, University of Bristol. UK

Email: sweetpea1905@gmail.com

Diterima pada 20 Oktober 2014, Disetujui pada 5 Januari 2015

\begin{abstract}
Abstrak
Konsep Kemanan Manusia lebih menekankan pada manusia sebagai subjek dari studi keamanan, mencoba menggantikan posisi Negara sebagai subek keamanan. Beberapa penelitian mencoba untuk memisahkan kedua konsep ini, konsep kamanan Negara dan manusia. Namun ternyata, kedua konsep ini memiliki keterkaitan yang kuat satu sama lain. Negara memiliki peranan penting dalam menyediakan keamanan bagi warganya. Melalui kontrak sosial dan perlindungan keamanan sosial, Negara berkewajiban untuk menjadikan keamanan masyarakatnya sebagai tujuan akhir kebijakan keamanan negara.

Kata Kunci: keamanan manusia, kontrak sosial, keamanan nasional, perkembangan
\end{abstract}

\begin{abstract}
Human Security notion is emphasizing on human as the central of security studies, challenging the position of state as the core of security. Some studies are tried to separate the state security and human security, however there are strong connection between these two notions. State has important role in establishing and maintaining the security of its own citizens. Through social contract and social security protection, state are oblige to set the security of its own people as their security goal.

Key Words: human security, social contract, national security, development
\end{abstract}

\section{INTRODUCTION}

The end of the Cold War created a new stage of security matters. The decline of inter-state wars was replaced by the increasing number of intra-state wars that have been recognized as 'civil wars'. Poverty, famine, political oppression and violence, ethnic- and religious-based conflict, terrorism, environmental degradation, and pandemic disease are the new threats to global security today. Traditional concepts view the threats to security as coming from outside or from invasion by other countries, and the focus of security is sovereignty of state. On the other hand, the concept of human security places the individual or human as the focus of security.

In 1994, the United Nation Development Program (UNDP) Report introduced the concept of Human Security, and ever since there has been debate about the broadening the concept of security. The report addressed the new problem faced by most societies in the world, the feeling of insecurity that comes from daily life rather than from dreadful world events (UNDP, 1994). Kaldor (2007) sums up the concept of threat as something that not only comes from daily activities such as the economy, food, health, or environment, but also from political and societal sectors as well. 
Different approaches are used to embrace the notion of Human Security. The first, called the narrow school approach, emphasizes the role of the state in creating difficulty for its own citizens in the forms of war, political violence, tyrannical government, corruption, and insecurity from civil actors (non-state actors) in the form of ethnic or religious conflicts. As Mack (2004, cited in Kerr, 2007, p.106) argued, the narrow school approach defined human security as 'freedom from fear', as in fear from any kinds of violence. The second approach is called the broad school, which interprets human security as 'freedom from want' and emphasizes development as the solution for security matters (Kaldor, 2007; Kerr, 2007).

The Post-Cold War condition also triggered the emergence of security providers other than the state, such as international institutions, NGOs, and civil society. Buzan (1991) argued that it will be difficult for the state to take part in the human security agenda as the state, in many situations, is the perpetrator of violence and a source of human insecurity. However in addressing human security, the participation of the state is still important. Kerr (2007) stated that not all states are violent toward their own people and many states are changing to accommodate human security as part of their national security agenda.

This essay attempts to analyze the significant role that the state played in the human security agenda in Canada, Japan, and Brazil. Sometimes the state can be the source of violence, but the state also has a responsibility to protect the rights of its citizens. To support this argument, the essay will present the state as a provider for human security and reviews the assertion of the UNDP, which suggests that there is a shifting paradigm of security from state-centric to humancentric security and how the UNDP views the state in creating difficulty and also providing security for the citizens. The second argument is that the state should provide protection on the basis of social contracts to create development to provide equal distribution of welfare to society.

\section{ANALYSIS}

\section{SHIFTING THE SECURITY AGENDA}

Security studies have been dominated by discussions on the security of the state. Protecting the sovereignty and territory by military means is the main focus of the global security agenda. However, many scholars have argued that the success of maintaining territorial security is not inherent to the security of people within the state (King and Murray, 2002). The question of human survival was the focus of the UNDP new agenda Human Security publication in 1994. The UNDP Report stated that "human security is not a concern with weapons - it is a concerned with human life and dignity". The biggest threat to humans is no longer from war, but is related to daily life, and includes job scarcity, economic disparity, underdevelopment, famine, pandemic disease, and environmental degradation (UNDP, 1994).

The UNDP defines human security with two terms: 'freedom from fear' and 'freedom from want' (UNDP, 1994; Mack, 2004). The freedom from fear includes personal, community, and political security, which are usually associated with violence or are threats. The freedom from want is related to the establishment of sustainable human development to achieve human security. This includes economic, food, health, and environmental security.

The decreasing number of interstate wars does not mean human security is decreasing as well. The Canadian government is adopting the concept that human security has increasingly centered on the human costs of violent conflict. The concept of 'new war' was introduced by Kaldor (1999) and suggests that civilians are the direct target of violence. Boutros-Ghali (1992, cited in Duffield, 2007) stated that the new form of war was "often of religious or ethnic character often involving unusual violence and cruelty". The survival of people is in danger where civil war targets civilians and destroys vital public infrastructures, which can make the condition worse.

The 1994 UNDP Report recognized forms of individual, community and political violence. Human rights violations were the most frequent during 
periods of conflict. Individuals and communities are threatened by the increasing number of violent crimes, ethnic cleansing, insurgency, and political violence done by the state. The 2013 UNDP Report announced that political instability created human insecurity: 45 million of people were forcibly displaced due to conflict or prosecution by the end of 2012 - the highest in 18 years - and more than 15 million of them were refugees. In many areas in the world, such as in West Africa, Central Africa, Latin America and Caribbean, the lack of law enforcement, increases in armed conflict, and rising rates of homicide and other violent crime have threatened human life and jeopardized human development and national progress (UNDP, 2013).

In many circumstances, the state is the cause of violence to its own citizens. The phenomena of weak states where weak governmental institutions, lack of law enforcement, and the corruption of the elites cause suffering by the people who live within that particular state. In the case of Uzbekistan as a weak state, there was a feeble statehood that caused high rates of organized crime, terrorism, and anti-government movements. To overcome these problems, the Karimov Regime used violent and political oppression (Jackson, 2007). Due to this condition, Jackson added that people in Uzbekistan live in an insecure environment where the threats are coming from both government and non-government directions.

The conception of weak or failed state is often characterized by the loss of control of state over its peripheral regions, disharmony between communities, rapid growth of criminality, drop in GNP, high number of corruptions, and high poverty rates within society (Call, 2008). Through the characteristics of failed state, the linkage between state incapacity to manage and provide security for its territory and citizens, and internal stability among the poor, marginalize societies, and violation of human rights are prominent. State dysfunction leads to the limited, or not so exaggerated to say, the absence of access to the basic needs of society (e.g. food, shelter, health, and physical security). Somalia has been used as one of examples of failed state in which this country has been without a legitimate central government since the collapse of the Siad Barre regime in 1991 (Hammond, 2013). This state has struggled with insurgency and counter-insurgency since 1991, and in 2004 the transitional federal government seemed incapable to cope with the problems. In results unending civil wars, massive famine, thousands of displace people, high rates of illegal economic sectors, criminality, and piracy have jeopardized the Somalian people's life (Hammond, 2013).

The government of Canada is an example of a state that is unable or unwilling to protect the security of its citizens and appears to have concern with human security from a perspective of violent conflict, protection and humanitarian intervention (Duffield, 2007). Under the Responsibility to Protect, every state has the responsibility to protect the rights of its own people. Other states or the international community also has a responsibility to protect people within a certain state if the people are suffering serious harm and the host state fails to provide protection (ICISS, 2001). The Responsibility to Protect has generated debate within the international community, where this concept attempts to overcome and prevent human rights violation, but is against the fundamental sovereignty of a state to intervene. In 2005, the United Nations agreed to take serious steps to ensure that every state must take responsibility to protect the security of human populations and encouraged the international community to take collective action if a state failed to protect its population (UN, 2005).

Canada supports state intervention as part of human security protection. The lesson from the genocide and ethnic cleansing in Kosovo made it necessary to take intervention as an action to prevent further conflict and human rights violations (Heinbecker, 2001). Heinbecker added that the threat and use of military forces would be used when necessary to back diplomacy during a conflict. Canada's support for human security is reflected through its efforts to promote human security as the main focus in the UN Security Council's agenda. Canada and 
Norway have joined in establishing the Human Security Partnership, which is concerned with human insecurity as result of violent conflict (Acharya, 2001). The partnership focuses on a nine-point agenda of human security: prohibition of landmines, formation of International Criminal Court, human rights, international humanitarian law, women and children in armed conflict, small arms proliferation, child soldiers, child labor, and northern co-operation (Ottawa Citizen, 1998, cited in Acharya, 2001, p.446).

The UNDP emphasized the important of sustainable development to ensure the security and wellbeing of human life. Human security through the pursuit economic growth is not the main goal of the state, but economic growth is a means for the state to provide for the welfare of the people (UNDP, 1994). Duffield (2001) argued that there is a close relationship between development and security. Underdevelopment can generate insecure conditions for the people, the state and the international environment. Unemployment, global poverty, poor healthcare, unknown disease, transnational crime, and environmental degradation are new threats to human survival. The UNDP (1994) stated that "sustainable development is pro-people, pro-jobs and pro-nature". The balance between economic growth and environmental preservation is a basic requirement to create long-last improvement in human life for both the present and future. Sustainable development is about creating diversity of choice for people to manage risk and preserve their domestic security (Duffield, 2007).

A different approach was taken by the government of Japan regarding human security. Japan tried to uphold a broader view of human security with regard to development that was more in line with the UNDP proposal (Duffield, 2007). Japan criticized the Canadian approach to human security as too narrow and argued that human security included freedom from fear and freedom from want. In 1995 the Japan Prime Minister, Tomiichi Murayama, addressed human security as a new strategy for the United Nations that should include protecting human life from both conflict situations and starvation (Acharya, 2001). People suffer from the collapse of economic conditions, causing them difficulty in finding jobs, declines of income, and declines of life quality. Poverty and famine in the South also generate human travails as immense as those caused by violent conflict. Based on Japan's Ministry of Foreign Affairs, the state has actively promoted public understanding and awareness of human security through international symposiums since 2002 (MOFA, 2009). Leadership in Japan has suggested that development is a tool to protect human life and initiated the establishment of The Trust Fund for Human Security, which is managed in partnership with UN Secretariat (MOFA, 2009).

Even though there are different approaches to understand human security, including narrow and broad schools, the primary object to be secured is human survival, not the territory of the state. Humancenter security does not directly undermine the role of the state as security actor. Despite the emergence of other security actors such as international organizations, NGOs, and private security companies, the state is still the main security guarantor for its people. The United Nations interpreted the sovereignty of state as a form of responsibility and not only authority: "sovereignty no longer exclusively protects States from foreign interference; it is a charge of responsibility that holds states accountable for the welfare of their people" (UN, 2005). The state also becomes the promotor of the establishment of human security as part of basic policy making. Canada, Norway, and Japan are examples that states can be significant actors to promote and uphold human security values. The UNDP has also encouraged the participation of nation states to implement human security in their national and foreign policies, and embolden the cooperation among nation states to create global development to counter the problem related to humanity (UNDP, 1994).

\section{MAKING LINKS BETWEEN SOCIAL CONTRACTS AND THE RESPONSIBILITY OF THE STATE}

Human security is understood as securing the 
people rather than the state and involves decreasing the involvement of the state as a security actor. However, it can be seen that "the ultimate responsibility for securing humans is passed back to the state" (Duffield, 2007). This responsibility to protect its own citizens is embedded in the value of social contracts between the state and its own people. The notion of "social contract" is important to explaining the reasons why the state should be responsible for the security and welfare of its constituents.

For many reasons, human insecurity is the result of the violation of social contracts. Within the European Union, state fragility, poverty, and underdevelopment have occurred when:

The social contract is broken due to the state incapacity or unwillingness to deal with its basic functions, meet its obligation, and responsibilities regarding the rule of law, protection of human rights, and fundamental freedoms, security and safety of its own population, poverty reduction, service delivery, the transparent and equitable management of resources and access to power. (EU, 2009)

The social contract theory was developed in Europe during the seventeenth and eighteenth centuries by Thomas Hobbes, John Locke, and Jean-Jacques who were the three classical expositors of the doctrine (Forsyth, 1994). However, Lessnoff (1990) stated that the earliest contractarian analyses of political authority was concerned with the relation between 'ruler' and 'people' was founded by Alastian Monk, Manegold of Lautenbach, in which authoritative power was not absolute and the power itself contained obligations for the ruler to protect its people from tyranny. In 1972, John Rawls extended the social contract theory into more comprehensive analysis in which he added both political authority of the ruler and legitimacy from society (Hickey, 2010). Rawls argued that people take collective action to establish governing institutions where they agree to obey the rules of political authority if the ruler agrees to fulfill basic freedoms and equality in return. Jennings (1994) argued that in the Jane-Jacques Rousseau perspective of social contract, men have liberty and law if they "construct a society where they ruled themselves". In the other words, social contract theory explains the construction of statehood and state-society relations where members of the society agree to build a state and the source of authority and sovereignty comes from the society itself. Rousseau believed that the content of the social contract agreement benefits all. It can be seen that booth Rawls and Rousseau promote commonwealth, equality-based social justice, and also create mutual benefits for both the ruler and society (Hickey, 2010P).

The idea of sacrificing certain individual rights to create government is also reflected by the concept of democracy, which is in contrast with Hobbes' social contract where social justice is provided by an absolute autarchic state system (Forsyth, 1994). In such situations, members of the society have made agreements to sacrifice some of their liberties and give the sovereign right to be governed by a few people whom they already elected through the democratic process. Based on the French Revolution, Rousseau argued that the democracy system is the best state system to maintain social contracts between the state and it citizens (Jennings, 1994). Democratic state systems, according to Rousseau, advocate individual liberty and sovereignty to avoid tyrannical state systems. Accountability and transparency brought by democracy ensure societal monitoring of government responsibilities in terms of distributing social protection and welfare to society. Support from the people, or at least the majority of people, is needed to build a stronger and more effective state that provides social protection and welfare (Jennings, 1994).

The state has been taking responsibility for human security, such as providing security from violent crime and regimes and access to education, health, jobs, and a strong economy as part of the social promise. In return, society has to conduct good behavior based on the rule of law and contribute to the social order. A social contract not only requires social obedience where members of society contribute to the state, but also explains the politics of taxation. Tax is one 
reflection of the link between the social contract and social protection. The state has the right to decide the amount of tax that society must pay. Taxpaying is one method that increases an individual's sense of ownership of the state and guarantees the accountability of the state (Prichard, 2009). Moore (2008) explained that people often demand more accountability by the state since taxes are already being paid. Taxes often bind society to following the rules of statehood, where sanctions are given to those who do not or are unwilling to pay. However, the good side of taxation for society is the tax revenue that can be used to pay for public infrastructure, education, healthcare, and civil security (Moore, 2008).

The notion of social contracts has created the normative ground for relations between the state and its citizens in the form of social protection. Social protection should be provided by the state in terms of both physical security of the individual and social welfare. The Organization for Economic Co-operation and Development (OECD) developed two different functions of the state: managing the general public services, which included firstly education, economy, health, housing, environmental protection and secondly public order and defense (OECD, 2011). Physical protection or the freedom from fear can be generated from the social contract, which comes from democratic state systems and taxation. The protection from fear is managed by the state with its function to provide defense by the military, while public order is provided by police services, laws court and prisons. Tax revenue enables the state to provide physical security by forming the police departments, paying government employees, and building infrastructure like courts and prisons. The state creates police department and sets up laws to restrain and protect society at the same time. Laws help restrain individuals' behavior and liberty without violating others' rights. Police departments have obligations to maintain social order and protect society from any kind of violent crimes, and with the rule of law, the state should create equal justice and non-discrimination regulations for citizens. Not only do the police and laws create security, but democratic state systems also guarantee the liberty and rights of individuals by promoting social participation, non-oppressive political systems, transparency, and accountability of the state to create social security or so-called democratic peace (Ramia, 2002).

People in some states suffer from discrimination based on race, religion, ethnicity, gender, and economic status. Changing laws and norms can reduce group disparities. Based on the 2014 UNDP Report, some countries like Brazil, South Africa and Malaysia adopted affirmative action to overcome discrimination and increase social protection for citizens. In 2012, Brazil passed a law mandating the reduction of racial disparities at school for its Afro-Brazilian and mix-race populations (UNDP, 2014). The apartheid legacy in South Africa is the background of discrimination in the workplace. The South African government created affirmative action policies for Black people, females, and other minorities to create a balance of job distribution for all society. In 2009, discrimination, unemployment, and poverty were reduced because of this policy (Maisannave, Decaluwe, and Chitiga, 2009, cited in UNDP, 2014, p.104).

The state has authority to regulate not only their people, but also the surrounding environment to support the progress of sustainable societal welfare. The state can regulate the market, social insurance and taxation as generators for a range of public infrastructures, such as health care, education, food supplies, job availability, public transportation, and pension protection (McKinnon, 2006 cited in Duffield, 2007, p.17). The liberal market system has limited the projection of human security, while the combination of market systems and social protection are aimed to create equal distribution of economic welfare (Ramia, 2002). Ramia added that the notion of social protection is a set of policies and regulations to protect individuals from the disadvantageous effect of market forces and includes regulation of minimum wage, occupational health and safety, (maximum) hours of work, employment protection, and paid and unpaid leave. Brazil has adopted human security-based policy 
as its social protection policy. Economic and tax reform are used to distribute welfare for its people. Brazil experienced a 7 percent increase in tax revenue as a percentage of GDP between 1995 and 2010. Political commitment to impose higher tax rates on large companies has helped the state to deliver economic welfare to its poorest citizens (Tax Justice Network, 2014).

Some scholars argue that the implementation of globalization and market economic systems as part of neo-liberal products, will limit the involvement of the state in economic sectors (Hynek, 2011). The market system may allow local producers to compete with international producers with fewer state regulations. Developing countries may find it difficult to compete because of limited technology and capital to develop their domestic products. However, the government can protect their local producers by promoting fair trade with the international parties. The government has a critical responsibility for managing foreign trade partners by engaging in advantageous trade negotiations that help ensure the international trade is conducted through fair trade principles. The government of Brazil implemented a mix of policy interventions aimed at boosting the job market, targeting government spending and cash transfers, expanding universal primary schooling and redressing gender and racial disparities (UNDP, 2014).

\section{CONCLUSION}

Human security puts human survival as the focus of the security agenda. To achieve the protection of human rights, the role and participation of the state is crucial. Although different approaches are used to view human security and protection from violent conflict and underdevelopment, countries such as Japan, Canada, and Brazil are actively adopting and promoting human security as a primary security and foreign policy agenda. Canada adopt the human security as responsibility to protect. Japan implement the broader view of human security and include development in security matters. And Brazil implementing the social contract to provide the security and protection for its people. Through its reports, the UNDP also recognized the important of state action and regulation in protecting human life based on human security values.

Moral responsibilities of the state toward its own citizens are the basic normative foundation for to the development of human and social protection. The social contract notion gives sovereignty and authority to the state to rule and create order within its society and at the same time obliges the state for the security and welfare of its citizens. The state's function to govern is one of the tools used to establish regulations which are pro-human, pro-employment, and proenvironment. Such functions will strengthen the position of the state as the provider of human security.

\section{BIBLIOGRAPHY}

Acharya, A., 2001. Human Security: East versus West. International Journal [e-journal] 56(3), 442-460. Available at <http:// www.jstor.org/stable/40203577> [accessed 22 December 2014]

Buzan, B., 1991. People, States and Fear: An Agenda for International Security in the Post-Cold War Era $2^{\text {nd }}$ Edition. London: Harvester Wheatsheaf.

Call, C.T., 2008. The Fallacy of the 'Failed State'. Third World Quarterly [e-journal], 29(8), 1491-1507. Available at < http://dx.doi.org/ 10.1080/01436590802544207> [accessed 23 May 2015]

Duffield, M., 2007. Development, Security and Unending War: Governing the World of People. Cambridge: Polity Press.

EU, 2009. Overcoming Fragility in Africa: Forging a New European Approach. European Report on Development 2009. Brussel: European Communities. Available at $<$ http://erd.eui.eu/media/ fullreport/ERD\%202009_EN_LowRes.pdf> [accessed 22 December 2014]

Forsyth, M., 1994. Hobbes's Contractarianism: A Comparative Analysis. In: D. Boucher and P. Kelly, ed. 1994. The Social Contract from Hobbes to Rawls. London: Routledge. Ch.2.

Hammond, L., 2013. Somalia Rising: Things Are Starting to Change for the World's Longest Failed State. Journal of Eastern African Studies [e-journal], 7(1), 183-193. Available at <http://dx.doi.org/10.1080/ 17531055.2012.755316> [accessed 23 May 2015]

Heinbecker, P., 1999. Human Security. Canadian Foreign Policy Journal [e-journal] 7(1), 19-25. Available at <http://www.tandfonline.com/ loi/rcfp20> [accessed 22 December 2014]

Hickey, S., 2010. The Politics of Social Protection in Africa: What do We Get from A 'Social Contract' Approach?. In: European Report on Development, Conference on "Experiences and lessons from social protection programs across the developing world: what role for EU?". Paris, France, 17-18 June 2010. Brussel: European Communities.

Hynek, N., 2011. Rethinking Human Security: History, Economy, 
Governmentality. In: D. Chandler and N. Hynek, ed. 2011. Critical Perspective on Human Security: Rethinking Emancipation and Power in International Relations. Oxford: Routledge.

ICISS, 2001. Responsibility to Protect. Ottawa: International Development Research Center. Available at <http:// responsibilitytoprotect.org/iciss\%20report.pdf > [accessed 22 December 2014]

Jackson, R., 2007. Regime Security. In: A. Collins, ed. 2013. Contemporary Security Studies $3^{\text {rd }}$ Edition. Oxford: Oxford University Press. Ch.12.

Jennings, J., 1994. Rousseau, Social Contract and the Modern Leviathan. In: D. Boucher and P. Kelly, ed. 1994. The Social Contract from Hobbes to Rawls. London: Routledge. Ch.6.

Kaldor, M., 1999. New and Old Wars: Organised Violence in A Global Era. Cambridge: Polity Press.

Kaldor, M., 2007. Human Security. Cambridge: Polity Press.

Kerr, P., 2007. Human Security. In: A. Collins, ed. 2013. Contemporary Security Studies $3^{\text {rd }}$ Edition. Oxford: Oxford University Press. Ch.2.

King, G. and Murray, C.J.L., 2002. Rethinking Human Security. Political Science Quarterly [e-journal] 116(4), 585-610. Available at < http:// www.jstor.org/stable/79822> [accessed 22 December 2014]

MOFA, Ministry of Foreign Affairs of Japan, 2009. Human Security: for the "Human-Centered" $21^{\text {st }}$ Century. Available at < http:// www.mofa.go.jp/policy/human_secu/t_fund21.pdf $>$ [accessed 22 December 2014]

Moore, M., 2008. Between Coercion and Contract: Competing Narratives around Taxation and Governance. In: D. Brautigam, O. Fjeldstad and M. Moore, ed. 2008. Capacity and Consent: Taxation and State Building in Developing Countries. [E-book] Cambridge: Cambridge University Press. Available through: Cambridge Books Online < http://ebooks.cambridge.org/ ebook.jsf? bid =CBO9780511490897 $>$ [accessed 22 December 2014]

Newman, E. and Richmond, O.P. ed., 2001. The United Nation and Human Security. London: Palgrave.

OECD, 2011. Government at a Glance. Available at <http:// www.oecd.org/gov/48250727.pdf> [accessed 22 December 2014]

Prichard, W., 2009. IDS Working Paper 330: The Politics of Taxation and Implications for Accountability in Ghana 1981-2008. Brighton: Institute of Development Studies. Available at < http:// www.ids.ac.uk/files/dmfile/Wp330.pdf > [accessed 22 December 2014]

Ramia, G., 2002. The 'New Contractualism' Social Protection and the Yeatman Thesis. Journal of Sociology [e-journal] 38(1), 49-68. Available at $<$ http://jos.sagepub.com/content/38/1/ 49.full.pdf +html> [accessed 22 December 2014]

Tax Justice Network, 2014. Guest Blog: Tax and the Social Contract in Brazil. Available at < http://www.taxjustice.net/2014/10/13/guestblog-tax-social-contract-brazil/> [accessed 22 December 2014]

Tehranian, M. ed., 1999. Worlds Apart: Human Security and Global Governance. London: I.B. Tauris.

United Nations, 2005. The Responsibility to protect. [Online] Available at <http://www.un.org/en/preventgenocide/adviser/ responsibilty.shtml $>$ [accessed 22 December 2014]

UNDP, 1994. Human Development Report 1994. New York: Oxford University Press. Available at <http://hdr.undp.org/sites/default/files/ reports/255/hdr_1994_en_complete_nostats.pdf > [accessed 22 December 2014]

UNDP, 2013. Human Development Report 2013. New York: UNDP. Available at <http://hdr.undp.org/sites/default/files/reports/14/ hdr2013_en_complete.pdf > [accessed 22 December 2014] UNDP, 2014. Human Development Report 2014. New York: UNDP. Available at <http://hdr.undp.org/sites/default/files/hdr14-report-en1.pdf $>$ [accessed 22 December 2014] 